Joyful Learning Journal

\title{
HUBUNGAN VARIASI MENGAJAR GURU DAN MOTIVASI BELAJAR SISWA DENGAN HASIL BELAJAR MATEMATIKA
}

\author{
Suhelin Setiyaningsih ${ }^{\bowtie}$, Ali Sunarso
}

Jurusan Pendidikan Guru Sekolah Dasar, Fakultas Ilmu Pendidikan, Universitas Negeri Semarang, Indonesia

\section{Info Artikel \\ Sejarah Artikel: \\ Diterima April 2020 \\ Disetujui Mei 2020 \\ Dipublikasikan Juni 2020}

\section{Keywords:}

learning motivation;

mathematics learning

outcomes; variaty of teaching

\begin{abstract}
Abstrak
Tujuan penelitian ini adalah menguji hubungan variasi mengajar guru dan motivasi belajar siswa dengan hasil belajar matematika siswa kelas IV SD Gugus Kenanga Kecamatan Pejagoan Kabupaten Kebumen. Penelitian ini menggunakan metode kuantitatif dengan jenis penelitian korelasi. Populasi dalam penelitian ini yaitu 112 siswa. Pengambilan sampel menggunakan metode Nonprobability Sampling, sedangkan cara pengambilan sampel yang digunakan adalah sampling jenuh sejumlah populasi. Teknik pengumpulan data menggunakan angket, dokumentasi, observasi, dan wawancara. Hasil penelitian menunjukkan adanya hubungan positif dan siginifikan antara variasi mengajar guru dan motivasi belajar siswa dengan hasil belajar matematika dengan rhitung $=0,8023$ (kategori sangat kuat) dan Fhitung $=98,5023$ serta berkontribusi sebesar $64,4 \%$. Dari hasil penelitian dapat disimpulkan bahwa ada hubungan yang positif dan signifikan antara variasi mengajar guru dan motivasi belajar siswa dengan hasil belajar Matematika siswa kelas IV SD Gugus Kenanga Kecamatan Pejagoan Kabupaten Kebumen.
\end{abstract}

\section{Abstract}

The purpose of this study was to examine the correlation between teacher teaching variations and student learning motivation with mathematics learning outcomes the 4th grade students in Cluster Kenanga Elementary School Pejagoan Kebumen. This research used quantitative method with the type of correlation research. The population in this study were 112 students. Sampling used Nonprobability Sampling method, while the sampling method used was saturated sampling. Data collection technique were questionnaires, documentation, observation, and interview. The results showed a positive and significant relationship between teacher teaching variation and student learning motivation with mathematics learning outcomes with rcount $=0.8023$ (very strong category) and Fcount $=98.5023$ and contributed $64.4 \%$. From the results of the study it can be concluded that there was a positive and significant correlation between teacher teaching variations and student learning motivation and mathematics learning outcomes the 4th grade students in Cluster Kenanga Elementary School Pejagoan Kebumen.

(C) 2020 Universitas Negeri Semarang

\footnotetext{
Alamat korespondensi:

Legok Pejagoan RT 05 RW 06, Kebumen

E-mail: helinsetiyani11.ss@gmail.com
}

ISSN 2252-6366 


\section{PENDAHULUAN}

Tercapainya tujuan pembelajaran dapat dilihat dari hasil belajar yang diraih oleh siswa setelah melaksanakan pembelajaran. Slameto (2013: 54) mengungkapkan ada dua faktor yang mempengaruhi hasil belajar siswa yaitu faktor internal dan faktor eksternal. Variasi mengajar guru merupakan salahbsatu faktor penunjang dalamiproses pembelajaran. Ada 8 variasi mengajar antara lain variasi suara, pemusatan perhatian siswa, kesenyapan, mengadakan kontak pandang, gerakan badan dan mimik, perubahan dalam posisi guru, variasi alat bantu pengajaran, dan variasi pola interaksi (Usman, 2016: 84).

Selain variasi mengajar guru, motivasi belajar juga menjadi hal yang perlu diperhatikan dalam belajar siswa. Menurut Sardiman (2018:75) motivasi dalam kegiatan belajar dapat diartikan sebagai keseluruhan daya penggerak dalam diri siswa yang menimbulkan, menjamin kelangsungan dan memberikan arah pada kegiatan belajar, sehingga tujuan yang dikehendaki oleh subjek belajar dapat tercapai. Variasi mengajar guru dan motivasi belajar memiliki dampak besar terhadap hasil belajar siswa. Menurut Uno (2016: 17) hasil belajar adalah pengalaman belajar yang diperoleh siswa dalam bentuk kemampuan tertentu.

Pada mata pelajaran matematika, pada dasarnya memerlukan ketelitian dan pemahaman dalam memperlajarinya. Matematika ialah ilmu yang bersifat universal yang memegang peran penting dalam pendidikan. Upaya guru dalam merancang pembelajaran merupakan bagian penting dalam keberhasilan siswa dalam mecapai tujuan pembelajaran, oleh karena itu pemilihan metode, pendekatan dan strategi pembelajaran guna tercapainya suasana pembelajaran yang aktif dan bermakna adalah tuntutan yang harus dipenuhi guru.

Berdasarkan hasil wawancara dan observasi yang dilakukan peneliti, terdapat permasalahan yang menyebabkan hasil belajar matematika siswa kurang optimal, antara lain pada saat pembelajaran guru belum sepenuhnya menerapkan variasi mengajar, pola interaksi yang digunakan dominan satu arah yaitu dari guru ke siswa. Akibatnya beberapa siswa kurang fokus saat pembelajaran. Beberapa siswa kelas IV di SD Gugus Kenanga Kecamatan Pejagoan Kabupaten Kebumen masih kurang menguasai pelajaran matematika dilihat dari hasil belajar yang belum mencapai batas tuntas.

Penelitian yang mendasari penelitian terkait, diantaranya adalah penelitian yang dilakukan oleh Lathifah Al Khumaero dan Sandy Arief tahun 2017 menunjukkan ada pengaruh gaya mengajar guru terhadap prestasi belajar pada mata pelajaran Ekonomi kelas Xl IPS SMA Negeri 1 Bawang Tahun Ajaran 2016/2017. Selanjutnya diperkuat oleh Achmad Djauhari tahun 2016 menunjukkan ada pengaruh yang signifikan gaya mengajar guru terhadap hasil belajar siswa SMP Negeri Satu Atap Plakpak Kecamatan Pegantenan
Kabupaten Pamekasan sebesar 13,3 atau 13,3\%. Kemudian penelitian yang dilakukan oleh Indah Ayu Lestari, Hermansyah Amir dan Salastri Rohiat tahun 2017 diperoleh nilai koefisien korelasi 0,232 > 0,11 (rhitung $>$ rtabel), dan nilai thitung $>$ ttabel $(4,312>1,967)$, yang menunjukkan bahwa ada hubungan positif yang signifikan antara persepsi siswa tentang variasi gaya mengajar guru dengan hasil belajar kimia siswa.

Jurnal penelitian internasional terkait diantaranya penelitian oleh Sedigheh Saravani, Afsaneh Marziyeh, dan Hossein Jenaabadi tahun 2017 menunjukkan bahwa dimensi variasi gaya pengajaran yang dirasakan dengan prestasi belajar matematika memiliki hubungan yang signifikan yang ditunjukkan dengan hasil uji t. Kemudian penelitian oleh Agus Muji Susanto, Mohamad Amin, Sutiman B Sumitro, dan Betty Lukiati tahun 2017 menunjukkan bahwa terdapat korelasi yang kuat dan positif antara self-efficacy and assessment anxiety dengan career motivation sebesar 0,669 dan antara self-determination dan grade motivation sebesar 0,768 . Selanjutnya penelitian oleh Sapta Dityawati dan Wuryadi tahun 2019 menunjukkan pengaruh motivasi belajar adalah 9,4\%; kemampuan guru untuk mengajar adalah 9,5\%; perhatian orang tua adalah $12,1 \%$ dan fasilitas belajar adalah 7,6\% terhadap pemahaman materi sistem regulasi dan secara simultan berdampak pada 20,3\% pada pemahaman materi sistem regulasi.

Tujuan dilaksanakan penelitian ini adalah sebagai berikut: (1) menguji hubungan variasi mengajar guru dengan hasil belajar matematika siswa kelas IV SD Gugus Kenanga Kecamatan Pejagoan Kabupaten Kebumen; (2) menguji hubungan motivasi belajar dengan hasil belajar matematika siswa kelas IV SD Gugus Kenanga Kecamatan Pejagoan Kabupaten Kebumen; (3) menguji hubungan variasi mengajar guru dan motivasi belajar dengan hasil belajar matematika siswa kelas IV SD Gugus Kenanga Kecamatan Pejagoan Kabupaten Kebumen.

\section{METODE PENELITIAN}

Penelitian ini merupakan penelitian kuantitatif jenis korelasi. Menurut Sugiyono (2016: 14) Metode penelitian kuantitatif merupakan metode penelitian yang berlandaskan pada filsafat positifisme, digunakan untuk meneliti pada populasi atau sampel tertentu.

Subjek pada penelitian ini adalah siswa kelas IV SD Negeri Gugus Kenanga Kecamatan Pejagoan Kabupaten Kebumen. Penelitian ini dilakukan di SD Gugus Kenanga Kecamatan Pejagoan Kabupaten Kebumen meliputi SD Negeri 1 Pejagoan, SD Negeri 2 Pejagoan, SD Negeri 4 Pejagoan, dan SD Muhammadiyah Pejagoan. Dalam penelitian ini peneliti menggunakan metode Nonprobability Sampling, dengan teknik sampling jenuh sebanyak 112 siswa. Variabel dalam penelitian ini terdiri dari variasi mengajar guru dan motivasi belajar siswa 
sebagai variabel bebas dan hasil belajar matematika sebagai variabel terikat.

Sugiyono (2016: 309) menyebutkan macam teknik pengumpulan data antara lain: (1) angket/kuesioner, (2) observasi, (3) wawancara, (4) dokumentasi. Sebelum instrumen penelitian digunakan, maka dilakukan uji coba. Selanjutnya peneliti menguji validitas dan reliabilitas instrumen tersebut. Teknik analisis data yang digunakan pada penelitian ini adalah: (1) uji prasyarat analisis meliputi uji normalitas, linieritas, dan multikolinieritas; (2) analisis statistik deskriptif; dan (3) analisis pengujian hipotesis menggunakan uji $t$, analisis product moment, korelasi ganda, uji F (signifikan), dan koefisien determinasi. Selain itu juga menggunakan transformasi data menggunakan Method of Successie Interval (MSI).

\section{HASIL DAN PEMBAHASAN}

Hasil penelitian hubungan variasi mengajar guru dan motivasi belajar siswa dengan hasil belajar Matematika siswa kelas IV SD Gugus Kenanga Kecamatan Pejagoan Kabupaten Kebumen, meliputi beberapa hal sebagai berikut.

\section{Hasil Analisis Deskriptif Variasi Mengajar (X1)}

Jumlah pernyataan dalam angket variasi mengajar guru terdiri atas 28 item. Variasi mengajar guru kelas IV SD Gugus Kenanga Kecamatan Pejagoan Kabupaten Kebumen dapat dilihat pada tabel berikut:

Tabel 1 Kategori Variasi Mengajar Guru oleh Siswa

\begin{tabular}{ccccc}
\hline Interval Skor & Kategori & Frekuensi & Presentase (\%) & Rata-rata \\
\hline $82-100$ & Sangat Baik & 54 & $48 \%$ & \\
$63-81$ & Baik & 50 & $45 \%$ & 80 \\
$44-62$ & Sedang & 8 & $7 \%$ & (BAIK) \\
$25-43$ & Kurang Baik & 0 & $0 \%$ & \\
\hline Jumlah & & 112 & $100 \%$ & \\
\hline
\end{tabular}

Sumber: Data penelitian (tahun 2020)

Tabel 2 Kategori Variasi Mengajar Guru oleh Guru

\begin{tabular}{ccccc}
\hline Interval Skor & Kategori & Frekuensi & Presentase $(\%)$ & Rata-rata \\
\hline $82-100$ & Sangat Baik & 0 & $0 \%$ & \\
$63-81$ & Baik & 5 & $100 \%$ & 79 \\
$44-62$ & Sedang & 0 & $0 \%$ & (BAIK) \\
$25-43$ & Kurang Baik & 0 & $0 \%$ & \\
\hline Jumlah & & 5 & $100 \%$ & \\
\hline
\end{tabular}

Sumber: Data penelitian (tahun 2020)

Berdasarkan hasil analisis deskriptif yang telah dilakukan, secara keseluruhan variasi mengajar guru yang diterima siswa pada pelajaran Matematika kelas IV SD Gugus Kenanga Kecamatan Pejagoan Kabupaten Kebumen termasuk dalam kategori baik. Hal tersebut didukung pula dengan hasil angket yang diisi oleh guru menyatakan variasi mengajar guru pada pelajaran Matematika dalalam kategori baik. $\mathrm{Hal}$ ini bertolak belakang dengan penelitian awal melalui wawancara dan observasi dengan guru yang menyatakan bahwa indikator variasi mengajar guru belum sepenuhnya diterapkan, karena guru merasa kesulitan cara menyampaikan pelajaran matematika yang tepat kepada siswa dan merasa bingung dalam menerapkan indikator variasi mengajar yang tepat.

\section{Hasil Analisis Deskriptif Motivasi Belajar (X2)}

Jumlah pernyataan dalam angket motivasi belajar terdiri atas 32 item. Motivasi belajar siswa kelas IV SD Gugus Kenanga Kecamatan Pejagoan Kabupaten kebumen dapat dilihat pada tabel berikut:

Tabel 3 Kategori Motivasi Belajar

\begin{tabular}{|c|c|c|c|c|}
\hline Interval Skor & Kategori & Frekuensi & Presentase (\%) & Rata-rata \\
\hline $82-100$ & Sangat Baik & 45 & $40 \%$ & \\
\hline $63-81$ & Baik & 64 & $57 \%$ & 79 \\
\hline $44-62$ & Sedang & 3 & $3 \%$ & (Baik) \\
\hline $25-43$ & Kurang & 0 & $0 \%$ & \\
\hline \multicolumn{2}{|c|}{ Jumlah } & 112 & $100 \%$ & \\
\hline
\end{tabular}

Sumber: Data penelitian (tahun 2020)

Berdasarkan hasil penelitian yang diperoleh dari analisis deskriptif, secara keseluruhan motivasi belajar siswa pada pelajaran Matematika kelas IV SD Gugus Kenanga Kecamatan Pejagoan Kabupaten Kebumen dalam kategori baik. Hal ini bertolak belakang dengan penelitian awal melalui wawancara dengan guru diperoleh informasi bahwa beberapa siswa belum sepenuhnya aktif dalam pembelajaran matematika ditunjukkan dengan tidak fokusnya siswa saat mengerjakan soal latihan atau tugas yang diberikan guru.

\section{Analisis Deskriptif Hasil Belajar Matematika} (Y)

Data nilai hasil belajar matematika diperoleh melalui dokumentasi nilai PAS siswa semsester 1 dan nilai Ulangan Harian I semester genap yang kemudian dicari rata-ratanya. Berikut tabel kategori hasil belajar siswa kelas IV SD Gugus Kenanga Kecamatan Pejagoan Kabupaten Kebumen.

Tabel 4 Kategori Hasil Belajar Matematika

\begin{tabular}{ccccc}
\hline Kategori & Nilai & Frekuensi & Presentasi & Rata-rata \\
\hline Sangat Baik & $86-100$ & 25 & $22 \%$ & \\
Baik & $71-85$ & 63 & $56 \%$ & 77 \\
Sedang & $56-70$ & 24 & $21 \%$ & (BAIK) \\
Kurang Baik & $\leq 55$ & 0 & $0 \%$ & \\
\hline Jumlah & & 112 & $100 \%$ & \\
\hline
\end{tabular}

Sumber: Data penelitian (tahun 2020)

\section{Transformasi Data}

Data yang didapatkan dari hasil angket variasi mengajar guru dan motivasi belajar berupa skala Likert yang merupakan data ordinal. Oleh karena itu, data dari skala Likert harus ditransformasikan dari data ordinal ke data interval menggunakan Method of Successie Interval (MSI). Sehingga diperoleh perubahan 
skor untuk variabel variasi mengajar guru yaitu skor 1 menjadi 1,000; skor 2 menjadi 1,870; skor 3 menjadi 2,590; dan skor 4 menjadi 3,748 . Sedangkan perubahan skor untuk variabel motivasi belajar yaitu skor 1 menjadi 1,000; skor 2 menjadi 1,940; skor 3 menjadi 2,678; dan skor 4 menjadi 3,808 .

\section{Uji Prasyarat Analisis \\ Uji Normalitas}

Uji normalitas yang digunakan dalam penelitian ini menggunakan rumus Chi Kuadrat, berdasarkan hasil uji normalitas data diketahui dari nilai Chi Kuadrat dari variasi mengajar guru, motivasi belajar siswa, dan hasil belajar secara berturut-turut adalah 9,5829; 2,1982; dan 10,6850 dengan rtabel 11,07 sehingga dapat dikatakan bahwa populasi tersebut berdistribusi normal.

\section{Uji Linieritas}

Hasil analisis uji linieritas variasi mengajar dengan hasil belajar matematika diperoleh Fhitung -0,013 < Ftabel 8,552, artinya terdapat hubungan yang linier antara variabel variasi mengajar dengan hasil belajar matematika. Pada uji linieritas variabel motivasi belajar dengan hasil belajar matematika diperoleh Fhitung - 0,008 $<$ Ftabel 253,146, artinya terdapat hubungan yang linier antara motivasi belajar dengan hasil belajar matematika. Dari hasil uji linieritas di atas dapat disimpulkan bahwa antara variabel bebas dan terikat dalam penelitian ini bersifat linier.

\section{Uji Multikolinieritas}

Selanjutnya dilakukan uji multikolinieritas antara kedua variabel bebas, pada pengujian tersebut tidak boleh terjadi multikolinieritas yang tinggi antara kedua variabel bebas. Berdasarkan uji multikolinieritas didapat rhitung $\leq 0,800$ yaitu 0,202 . Hal ini menunjukkan bahwa tidak adanya multikolinieritas karena rhitung tidak mencapai 0,800 . Maka dapat disimpulkan bahwa tidak ada korelasi antar variabel independen.

\section{Analisis Hipotesis}

Analisis hipotesis menggunakan uji t, analisis korelasi sederhana (product moment), uji $\mathrm{F}$, dan analisis korelasi ganda.

\section{Hubungan Variasi Mengajar Guru dengan Hasil Belajar Matematika \\ Signifikansi hubungan variasi mengajar} guru dengan hasil belajar matematika diketahui pada taraf signifikansi $5 \%$ hasil perhitungan thitung sebesar 8,226 > ttabel 1,98, sehingga korelasi dikatakan signifikan dan berlaku untuk populasi. Selanjutnya dilakukan analisis korelasi sederhana yaitu untuk mengetahui hubungan variabel variasi mengajar guru dengan hasil belajar matematika. Berdasarkan hasil perhitungan diperoleh rhitung $(0,617)>$ rtabel $(0,184)$ sehingga Ha1 diterima, tanda positif pada rhitung yaitu 0,617 menunjukkan bahwa hubungan yang terjadi adalah positif atau searah, artinya semakin baik variasi mengajar guru semakin baik pula hasil belajar matematika siswa. Hasil perhitungan koefisien determinasi, diperoleh kontribusi variasi mengajar guru dengan hasil belajar matematika siswa sebesar 38,1\% sedangkan sisanya $61,9 \%$ dipengaruhi oleh faktor lain.

Berdasarkan hasil perhitungan diatas, peneliti menyimpulkan bahwa ada hubungan positif dan signifikan antara variasi mengajar guru dengan hasil belajar matematika siswa kelas IV SD Gugus Kenanga Kecamatan Pejagoan Kabupaten Kebumen. Variasi mengajar guru memberikan sumbangan dalam meningkatkan hasil belajar matematika. Hasil penelitian ini diperkuat penelitian oleh Srie faizah Lisnasari dan Eninta Br Barus pada tahun 2019 menunjukkan hubungan variasi mengajar guru dengan hasil belajar siswa memiliki hubungan yang posisitif dan signifikan. Hal ini ditunjukkan dari hasil pengujian hipotesis diperoleh nilai rhitung $0,8638>$ rtabel 0,329 dan thitung 8,04 $>$ ttabel 2,0739. Selanjutnya penelitian yang dilakukan oleh Luvia Rahmi Wikanti pada tahun 2017 menunjukkan hubungan yang positif dan signifikan antara variasi gaya mengajar guru dan sikap belajar siswa secara bersama-sama dengan hasil belajar siswa kelas V SDN Gugus Muh Syafei Kabupaten Semarang ditunjukkan dengan besar koefisien korelasi sebesar 0,655 atau 65,5\% yang termasuk dalam kategori cukup kuat.

\section{Hubungan Motivasi Belajar dengan Hasil Belajar Matematika}

Signifikansi hubungan motivasi belajar dengan hasil belajar matematika diketahui pada taraf signifikansi $5 \%$ hasil perhitungan thitung sebesar $8,446>$ ttabel 1,98, sehingga korelasi dikatakan signifikan dan berlaku untuk populasi. Selanjutnya dilakukan analisis korelasi sederhana yaitu untuk mengetahui hubungan variabel motivasi belajar dengan hasil belajar matematika. Berdasarkan hasil perhitungan diperoleh rhitung $(0,627)>$ rtabel $(0,184)$ sehingga Ha2 diterima, tanda positif pada rhitung yaitu 0,627 menunjukkan bahwa hubungan yang terjadi adalah positif atau searah, artinya semakin baik motivasi belajar maka semakin baik pula hasil belajar matematika siswa. Hasil perhitungan koefisien determinasi, diperoleh kontribusi motivasi belajar dengan hasil belajar matematika siswa sebesar 39,3\% sedangkan sisanya $60,7 \%$ dipengaruhi oleh faktor lain.

Berdasarkan hasil perhitungan diatas, peneliti menyimpulkan bahwa ada hubungan positif dan signifikan antara motivasi belajar dengan hasil belajar matematika siswa kelas IV SD Gugus Kenanga Kecamatan Pejagoan Kabupaten Kebumen. Motivasi belajar memberikan sumbangan dalam meningkatkan hasil belajar matematika. Hasil penelitian ini diperkuat penelitian oleh Hendra Dani Saputra pada tahun 2018 menunjukkan motivasi belajar mempunyai hubungan yang positif dan signifikan dengan hasil belajar siswa ditunjukkan dengan nilai koefisien korelasi penelitian sebesar 0,860 dengan $\alpha=0,05$ dan koefisien korelasi pada tabel (rtabel $=0,349$ ) sehingga thitung $>$ ttabel dengan $=0,05$. Selanjutnya 
penelitian yang dilakukan oleh Anisa Ratri Cahyani tahun 2018 menunjukkan adanya hubungan yang positif antara motivasi belajar dan gaya belajar terhadap hasil belajar IPS siswa kelas V SDN Gugus Melati Kecamatan Banyurip Kabupaten Purworejo dengan nilai rhitung sebesar 0,775 dan rtabel 0,195 dengan nilai signifikansi 0,05.

\section{Hubungan Variasi Mengajar Guru dan Motivasi Belajar Siswa dengan Hasil Belajar Matematika}

Hasil penelitian menunjukkan ada hubungan yang signifikan dan positif antara variasi mengajar guru dan motivasi belajar siswa dengan hasil belajar matematika siswa kelas IV SD Gugus Kenanga Kecamatan Pejagoan Kabupaten Kebumen. Signifikansi hubungan variasi mengajar guru dan motivasi belajar siswa dengan hasil belajar matematika pada taraf signifikansi 5\% hasil perhitungan Fhitung sebesar 98,5023 selanjutnya dapat dikonsultasikan dengan Ftabel, dengan dk pembilang $=2 \mathrm{dan}$ dk penyebut $=112-2-1=109$ dan taraf kesalahan yang ditetapkan 5\%. maka Ftabel = 3,09. Dalam hal ini berlaku ketentuan bila Fhitung $>$ Ftabel maka koefisien korelasi ganda yang diuji adalah signifikan. Selanjutnya dilakukan analisis korelasi ganda yaitu untuk mengetahui hubungan variabel variasi mengajar guru dan motivasi belajar siswa dengan hasil belajar matematika. Berdasarkan hasil perhitungan diperoleh Rhitung $(0,8023)>$ Rtabel $(0,184)$ sehingga Ha3 diterima, tanda positif pada rhitung yaitu 0,8023 menunjukkan bahwa hubungan yang terjadi adalah positif atau searah, artinya semakin baik variasi mengajar guru dan motivasi belajar siswa maka semakin baik pula hasil belajar matematika siswa. Nilai 0,8023 menunjukkan besarnya koefisien korelasi termasuk dalam katagori sangat kuat. Hasil perhitungan koefisien determinasi, diperoleh kontribusi variasi mengajar guru dan motivasi belajar siswa dengan hasil belajar matematika siswa sebesar $64,4 \%$ sedangkan sisanya $35,6 \%$ dipengaruhi oleh faktor lain.

Berdasarkan hasil penelitian ini dapat disimpulkan bahwa terdapat hubungan yang positif dan signifikan antara variasi mengajar guru dan motivasi belajar siswa secara bersama-sama dengan hasil belajar matematika siswa kelas IV SD Gugus Kenanga Kecamatan Pejagoan Kabupaten Kebumen. Hasil penelitian ini diperkuat oleh Tsalis Khusna Jati pada tahun 2016 menunjukkan terdapat pengaruh yang signifikan antara variasi gaya mengajara guru dan motivasi belajar siswa secara bersama-sama dengan prestasi belajar siswa kelas IV SD ditunjukkan dengan $\mathrm{R}=0,570$ dan $\mathrm{p}=0,000$ dengan sumbangan efektif variasi gaya mengajar guru dan motivasi belajar terhadap prestasi belajar IPA sebesar 32,5\%.

\section{SIMPULAN}

Berdasarkan hasil analisis dan pembahasan penelitian ini, maka dapat disimpulkan antara lain: (1) ada hubungan yang positif dan dan signifikan antara variasi mengajar guru dengan hasil belajar matematika dengan rhitung $=0,617$ (kategori kuat) dan berkontribusi sebesar 38,1\%; (2) ada hubungan yang positif dan dan signifikan antara motivasi belajar dengan hasil belajar matematika dengan rhitung $=0,627$ (kategori kuat) dan berkontribusi sebesar 39,3\%; (3) ada hubungan yang positif dan dan signifikan antara variasi mengajar guru dan motivasi belajar siswa dengan hasil belajar matematika dengan rhitung $=0,8023$ (kategori sangat kuat) dan berkontribusi sebesar $64,4 \%$.

\section{UCAPAN TERIMA KASIH}

Ucapan terima kasih disampaikan kepada: Dr. Ali Sunarso, M.Pd., selaku dosen pembimbing, Ibu Dra. Sumilah, M.Pd., dan Ibu Trimurtini, S.Pd., M.Pd., sebagai mitra bestari dan Bapak Arif Widagdo, S.Pd., M.Pd., selaku penyunting Bahasa Inggris yang telah memberikan bimbingan dan masukan dalam penyusunan manuskrip.

\section{DAFTAR PUSTAKA}

Cahyani, Anisa Ratri. 2018. Hubungan Motivasi Belajar dan Gaya Belajar Terhadap Hasil Belajar IPS Kelas V SDN Gugus Melati Kecamatan Banyurip Kabupaten Purworejo. Joyful Learning Journal ISSN 2252-6366

Dityawati, Meilana Sapta dan Wuryadi. 2019. The Influence of Learning Motivation, Ability of Teachers to Teach,Parental Attention and Learning Facilities in Understanding Material ofRegulatory System in Senior High School. International Seminar on Science Education: Journal of Physics

Djauhari, Achmad. 2016. Pengaruh Gaya Mengajar Guru Dan Kebiasaan Belajar Terhadap Hasil Belajar. Jurnal Penelitian dan Pendidikan IPS (JPPI) Volume 10 No 3 310-321 ISSN : 1858-4985

Ihjon, Ahiri Jafar, dkk. 2017. Pengaruh Gaya Mengajar Terhadap Motivasi dan Prestasi Belajar Ekonomi Siswa SMA Negeri Berbasis K-13 Di Kabupaten Konawe Selatan. Jurnal Wahana kajian Pendidikan IPS Vol. 1, No. 1, e-ISSN: 2502-325X.

Khumaero, Lathifah A1. 2017. Pengaruh Gaya Mengajar Guru, Disiplin Belajar, dan Teman Sebaya terhadap Prestasi Belajar. Economic Education Analysis Journal. pISSN: 2252-6544, e-ISSN 2502-356X. 
Lestari, Indah Ayu. 2017. Hubungan Persepsi Siswa Kelas X MIPA Di SMA Negeri Sekota Bengkulu Tahun Ajaran 2016/2017 Tentang Variasi Gaya Mengajar Guru dengan Hasil Belajar Kimia”. Jurnal Pendidikan dan Ilmu Kimia : 1 (2) : 113-116 ISSN 22528075

Lisnasari, Srie Faizah,dkk. 2019. Hubungan Variasi Mengajar Guru dengan Hasil Belajar Siswa Di Kelas V SDN 105401 Namo Linting Kecamatan STM Hulu Sumatera Utara. Jurnal Curere Vol. 3, No. 1, p-ISSN: 2597-9507, e-ISSN: 25979515.

Ningrat, Sayu Putri. 2018. Kontribusi Gaya Belajar dan Motivasi Belajar Terhadap Hasil belajar Bahasa Indonesia. Jurnal Ilmiah Sekolah Dasar Volume 2, Number 3, P-ISSN: 2579-3276, E-ISSN: 25496174

Purbiyanto, Ryan. \& Rustiana, A. 2018. Pengaruh Disiplin Belajar, Lingkungan Keluarga, dan Motivasi Belajar terhadap Hasil Beljar Siswa. Economic Education Analysis Journal p-ISSN: 2252-6544, e-ISSN: 2502$356 \mathrm{X}$.

Saputra, Hendra Dani, dkk. 2018. Pengaruh Motivasi Terhadap Hasil Belajar Siswa SMK. Jurnal Inovasi Vokasional dan Teknologi Volime 18, Number 1, ISSN: 1411-3411, e-ISSN: 2549-9815.

Saravani, Sadigheh dkk. 2017. The Relationship of the Dimensions of Perceived Teaching Style with Students' Mathematics Achievement and Self-Efficacy. International Electronic Journal of
Mathematics Education. E-ISSN: 13063030 Vol. 12, No. 349-358.

Sardiman. 2018. Interaksi dan Motivasi Belajar Mengajar. Jakarta: Rajawali Press.

Slameto. 2013. Belajar dan Faktor-faktor Yang Memengaruhinya. Jakarta : Rins Cipta

Susanto, Agus Muji dkk. 2017.

Learning Motivation of Students During the Implementation of Lecturing Based in Silico Approach. International Journal of Research and Review. Vol. 4 Issue 9 ISSN: 2349-9788.

Sugiyono. 2016. Metode Penelitian Kuantitatif Kualitatifdan R\&D. Bandung: Alfabeta.

Uno, B. Hamzah. 2016. Teori Motivasi \& Pengukurannya. Jakarta: Bumi Aksara

Usman, Moh. Uzer. 2016. Menjadi Guru Profesional. Bandung: PT. Remaja Rosdakarya.

Warti, E. 2016. Pengaruh Motivasi Belajar Siswa terhadap Hasil Belajar Matematika Siswa SD di SD Angkasa 10 Halim Perdana Kusuma. Jurnal Pendidikan Matematika STKIP Garut Vo. 5 No. 2 ISSN: 20864280 .

Wikanti, Luvia Rahmi. 2017. Hubungan Variasi Gaya Mengajar Guru dan Sikap Belajar siswa dengan Hasil Belajar Siswa Kelas V SDN Gugus Muh Syafei Kabupaten Semarang. Joyful Learning Journal ISSN 2252-63 